\title{
In-vitro Screening of Antidiabetic and Antimicrobial Activity against Green Synthesized $\mathrm{AgNO}_{3}$ using Seaweeds
}

Abideen $\mathbf{S}$ and Vijaya Sankar $\mathbf{M}^{*}$

Research Department of Zoology, Dr. Zakir Husain College, Tamilnadu, India

\begin{abstract}
The present investigation was carried out the preparation and synthesis of silver nanoparticles in extract from Gracilaria edulis and Syringodium isoetifolium. Antidiabetic and Antimicrobial activity Study against different seven clinical pathogens Bacterial samples E. coli, Staphylococus, Streptococus, Shigella, Salmonella, Vibrio and Enterobacteria. The antidiabetic properties of Silver nano particles characterized with UV-Vis spectroscopy, FTIR, XRD, SEM and EDX. In this result biosynthesized silver nanoparticles using aqueous extract of Gracillaria edulis showed potential antibacterial activity with various bacterial pathogens which could be further used as a potential antibacterial agents, Similarly the assay results of silver nanoparticles showed Maximum concentration of $400 \mathrm{mg} / \mathrm{ml} 98.75 \%$ was recorded.
\end{abstract}

Keywords: Nanoparticles; Clinical pathogens; Antimicrobial activity; Antidiabetic properties

\section{Introduction}

Nanotechnology is one of the fastest developing sciences over the last few years. This is an inter-disciplinary science that connects knowledge of biology, chemistry, physics, engineering and material science [1]. Silver nanoparticles may reduce not only the number of pathogens in a wound, but also the inflammatory response. Antiinflammatory silver nanoparticles properties promote nanocrystalline dressings to heal chronic ulcers [2].

Seaweeds have been one of the richest and most promising sources of bioactive primary and secondary metabolites and their discovery has significantly expanded in the past three decades [3]. The Gracilaria species are important for the industrial and biotechnological uses because they have phycocolloids, the main source of agar $\alpha-(1,4)-3,6$ anhydro-L-galactose and $\beta$ - $(1,3)$-D-galactose with little esterification in cell wall [2]. Among the carbohydrates, agar and other polysaccharides are present in G. confervoides [4], G. dura, G. chilensi and G. secundata [5]. Diabetes mellitus (DM) is one of the most common lifestyle diseases. Type 2 diabetes had global prevalence estimate of $2.8 \%$ in the year 2000 and is projected to be $4.4 \%$ in 2030 [6]

Present experiment attempts to summarize the antidiabetic and antimicrobial activities of silvernano particles synthesized from Gracelliaria edulis and syringodium isoetifolium.

\section{Materials and Methods}

\section{Preparation of plant extract}

Fresh elder leaves from 3 mangrove plant species were collected from Gulf of mannar coastal area. The collected plant leaves were washed thrice in sterile distilled water to remove adhering soil particles and salts. The washed samples were shade dried for one week at room temperature. The leaves were cut in to small pieces and grained in to powder. The pure plant extract was prepared by adding $5 \mathrm{gm}$ of plant powder in to $100 \mathrm{ml}$ of distilled water and boiled for 5 minutes. The boiled extract was filtered through Watman No.1 filter paper and the supernatant was used and stored at $40^{\circ} \mathrm{C}$ for further process.

\section{Biosynthesis of silver nano particles}

In the typically synthesis process of silver nanoparticles, add $10 \mathrm{ml}$ of pure plant extract sample in to the $90 \mathrm{ml}$ of $1 \mathrm{mM}$ of silver nitrate solution in $250 \mathrm{ml}$ of conical flask. The reaction mixture was kept at room temperature under mechanically stirring. The colour change was noted and the nano particles formation was monitored.

\section{In-vitro Antidiabetic Assay}

In-vitro anti-hyperglycemic activity starch-iodine colour assay

Screening of Gracilaria edulis and syngcodium for a-amylase inhibitors was carried out according to Xiao [7] with slight modification based on the starch-iodine test. DMSO extract of Gracilaria edulis and syngcodium of varied concentrations in $500 \mu \mathrm{l}$ were added to $500 \mu \mathrm{l}$ of $0.02 \mathrm{M}$ sodium phosphate buffer ( $\mathrm{pH} 6.9$ containing $6 \mathrm{Mm}$ sodium chloride ) containing 0.04 units of $\alpha$ amylase solution and were incubated at $37^{\circ} \mathrm{C}$ for $10 \mathrm{~min}$. Than $500 \mu \mathrm{l}$ soluble starch $(1 \% \mathrm{w} / \mathrm{v})$ was added to each reaction well and incubated at $37^{\circ} \mathrm{C}$ for $15 \mathrm{~min} .1 \mathrm{M}$ HCL $(20 \mu \mathrm{L})$ was added to stop the enzymatic reaction followed by the addition of $100 \mu \mathrm{l}$ of iodine reagent (5 Mm 12 and mM KI). The colour change was noted and the absorbance was read at $660 \mathrm{~nm}$ on a microplate reader. The control reaction representing $100 \%$ enzyme activity did not contain any plant extract. To eliminate the absorbance produced by plant extract, appropriate extract controls without the enzyme were also included. Inhibition of enzyme activity was calculated as:

Inhibition of enzyme activity $(\%)=(\mathrm{C}-\mathrm{S}) / \mathrm{C} \times 100$, Where $\mathrm{S}$ is the absorbance of the sample and $\mathrm{C}$ is the absorbance of blank (no extract).

\section{Glucose movement by using dialysis membrane}

A simple model system was used to evaluate the effect of the seaweeds extracts Gracilaria edulis and syngcodium on glucose movement in vitro.

*Corresponding author: Vijaya Sankar M, Post-graduation and Research Department of Zoology, Dr. Zakir Husain College, Tamilnadu-630 702, India, Tel: +91 4564265252 E-Mail: chopade@unipune.ac.in

Received August 03, 2015; Accepted September 22, 2015; Published October 01,2015

Citation: Abideen S, Sankar MV (2015) In-vitro Screening of Antidiabetic and Antimicrobial Activity against Green Synthesized AgNO using Seaweeds. J Nanomed Nanotechnol S6-001. doi:10.4172/2157-7439.S6-001

Copyright: @ 2015 Abideen S, et al. This is an open-access article distributed under the terms of the Creative Commons Attribution License, which permits unrestricted use, distribution, and reproduction in any medium, provided the original author and source are credited. 
This model was adapted from a method described by Shaukat [8]. Briefly, the model used in the present experiment consisted of a one sided sealed dialysis tube $(15 \mathrm{~cm} 25 \mathrm{~mm}$, dialysis tubing membrane Himedia, Mumbai, India) into which $2 \mathrm{ml}$ of $22 \mathrm{Mm} \mathrm{D}$-glucose in $0.15 \mathrm{M} \mathrm{NaCl}$ and $1 \mathrm{Ml}$ extract $(160 \mathrm{mg} / \mathrm{ml}) /$ control (water) were incorporated. The other end was then sealed and the membrane was placed into a conical flask containing $45 \mathrm{ml}, 0.15 \mathrm{M} \mathrm{NaCl}$. The conical flask was placed into an orbital shaking incubator at $37^{\circ} \mathrm{C}$ and speed of 100 rotations per minute. Aliquote $(10 \mu \mathrm{l})$ of the external solution was withdrawn at timed intervals and tested for the presence of glucose using a glucose oxidase kit (Biosystem, Spain). As described by Gallagher [9] concentration dependent effect of seaweeds extracts that exhibited the highest glucose diffusion retardation index was also evaluated. A standard curve was drawn using different glucose concentrations. Experiments were conducted in triplicate. The glucose diffusion retardation index (GDRI) was calculated using the following formula.

GDRI $=(100-$ Glouse content $(\mathrm{mg} / \mathrm{mL})$ in external solution in the presence of seaweeds extracts /glucose contant $(\mathrm{mg} / \mathrm{mL})$ in external solution in the absence of seaweed extracts)

\section{In-vitro antimicrobial activity}

The bacteria culture was freshly cultivated for $24 \mathrm{hrs}$ in nutrient broth. Each bacterial culture was spread on the Muller Hinton agar plates. Sterile paper discs containing three different concentrations of silver nanoparticles were placed and incubated. The number of colonies was counted measured after the $42 \mathrm{hrs}$ of incubation. The same experiments were repeated for three times.

\section{Results and Discussion}

According to the literature studies, it is well known that the Silver nanoparticle solution has dark brown or dark reddish in colour. In Gracilaria edulis before addition of Silver nitrate solution its colour was dark grey but after its treatment with $\mathrm{AgNO} 3$, it colour changes to dark brown which showed the formation of Silver nano particles. Like other extract of Syringodium isoetifolium changed to dark brown after the treatment with $\mathrm{AgNO}_{3}$ (Figures 1-10).

\section{Inhibition of alpha amylase activity DNSA}

The result of the DNSA study is summarized in Table 1. The two different plant Gracillaria edulis and Syringodium isoetifolium showed significant effect on glucose utilization.

\section{Glucose diffusion inhibition test}

The result of the glucose diffusion inhibition test is given the Tables 2 and 3.

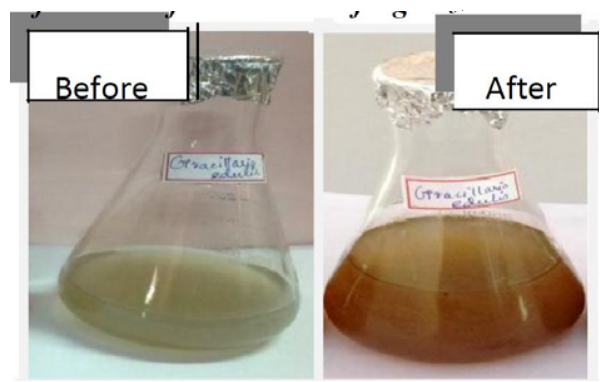

Figure 1: The colour change of Gracilaria edulis before and after addition of $\mathrm{AgNO} 3$ solution.

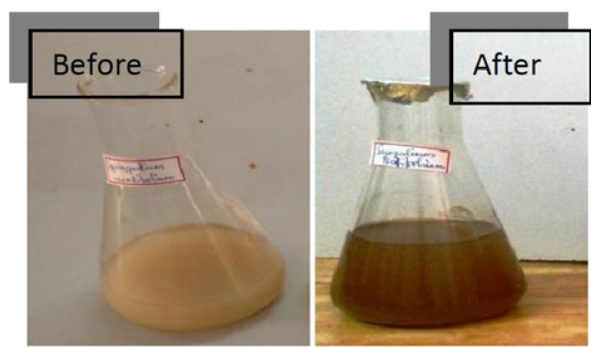

Figure 2: The colour change of Syringodium isoetifolium before and after addition of AgNO3 solution.

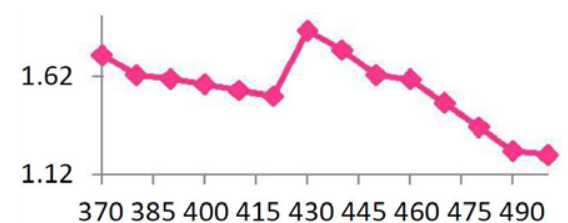

Figure 3: UV Visual absorbance peak of Gracilaria edulis.

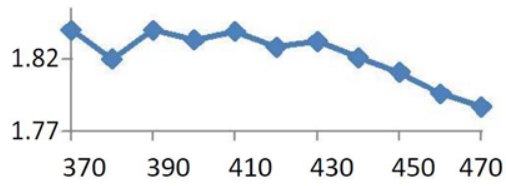

Figure 4: UV Visual absorbance peak of Syringodium isoetifolium.

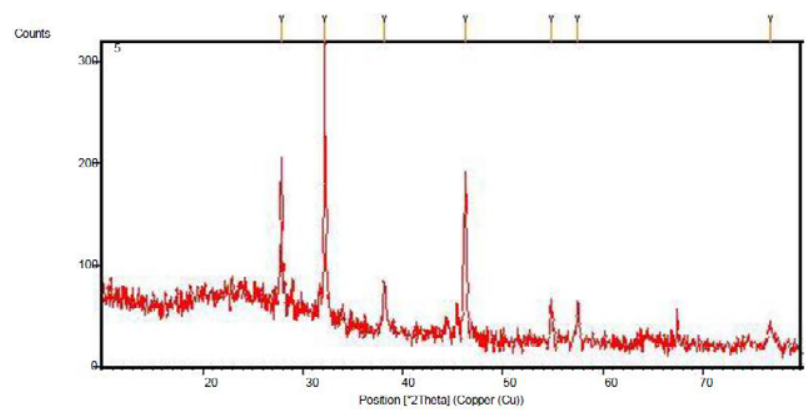

Figure 5: X-Ray Diffraction of silver nano particles synthesized from Gracilaria edulis.

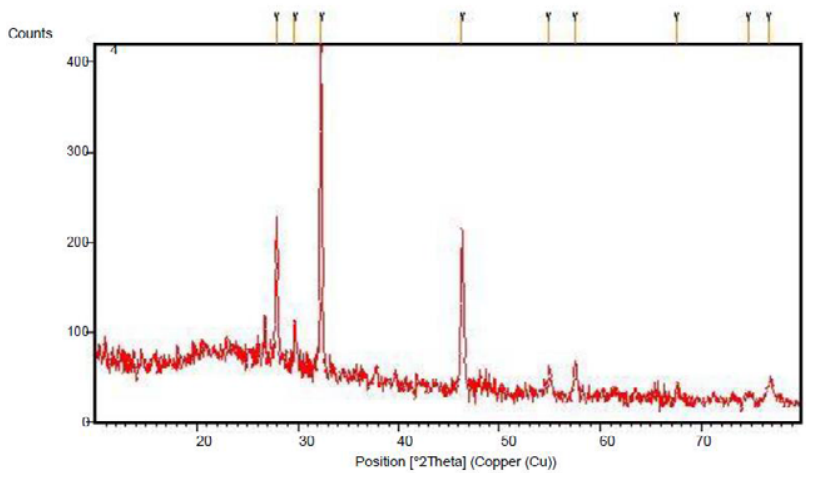

Figure 6: X-RAY diffraction of silver nano particles synthesized from Syringodium isoetifolium. 


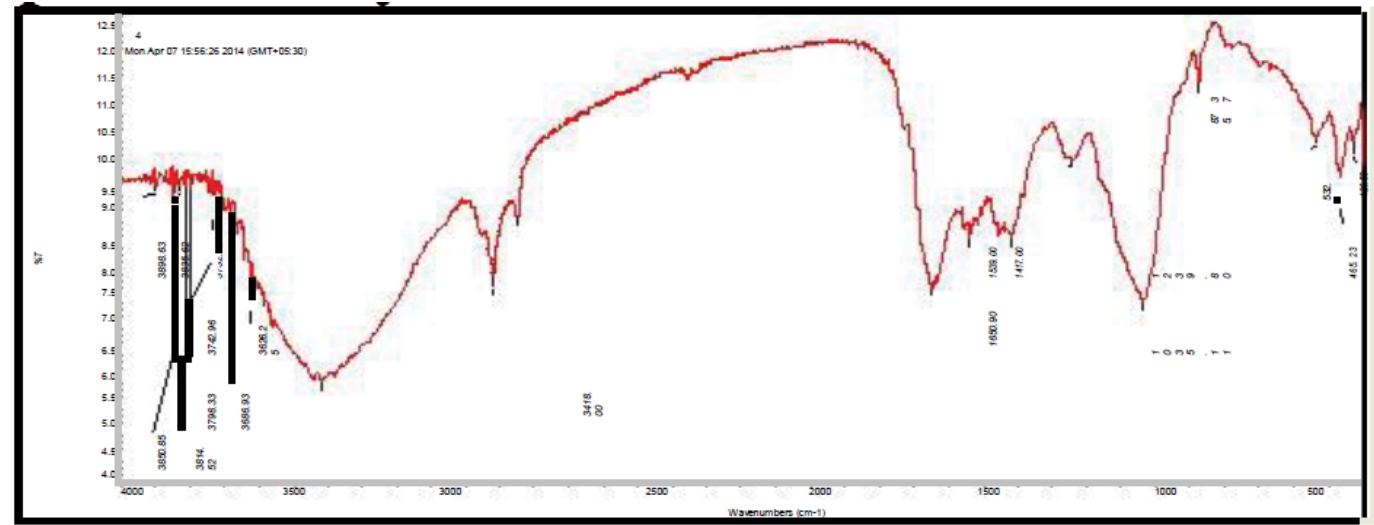

Gracilaria edulis.
\begin{tabular}{|c|c|c|}
\hline Peak & Bond & Functional group \\
\hline 875 & C-H “oop" & Aromatics \\
\hline 1035 & C-N stretch & Aliphatic amines \\
\hline 1239 & C-N stretch & Aliphatic amines \\
\hline 1417 & C-C stretch (in-ring) & Aromatics \\
\hline 1539 & N-O asymmetric & Nitro compounds \\
\hline & Stretch & \\
\hline 1650 & N-H bend & Primary amines \\
\hline 2852 & C-H stretch & Alkanes \\
\hline 2922 & C-H stretch & Alkanes \\
\hline 3418 & O-H stretch, H- bonded & Alcohols,phenols \\
\hline
\end{tabular}

Figure 7: FTIR analysis of silver nano particles synthesized from Gracilaria edulis.

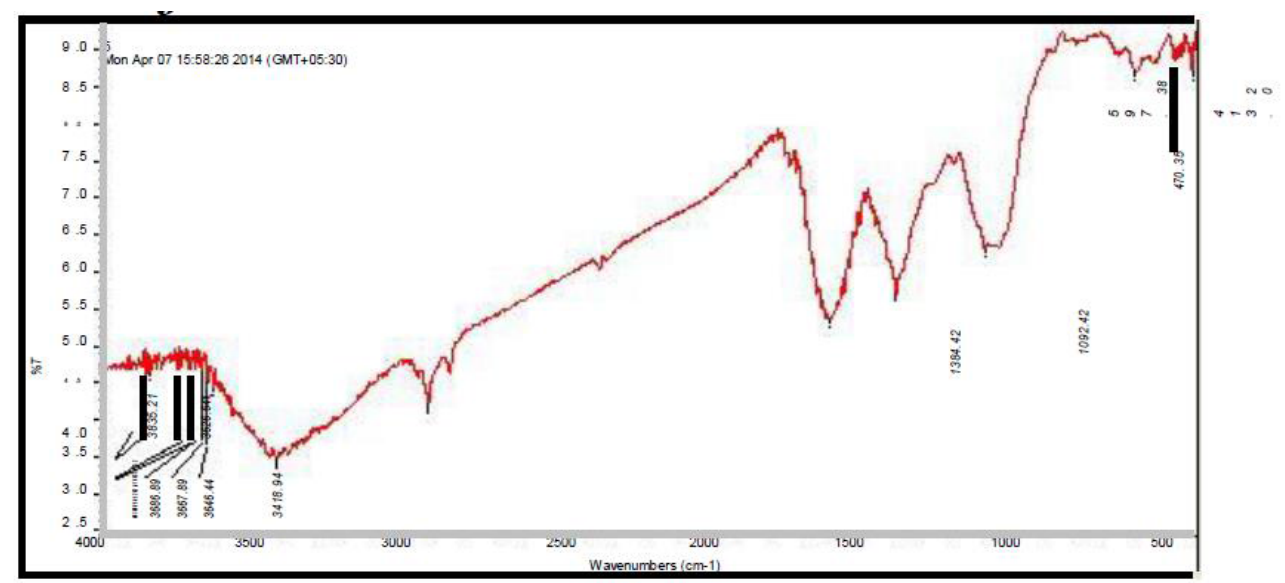

Syringodium isoetifolium

\begin{tabular}{|c|c|c|}
\hline Peak & Bond & Functional group \\
\hline 597 & C-Br stretch & Alkyl halides \\
\hline 1092 & C-N stretch & Aliphatic amines \\
\hline 1384 & - & \\
\hline 1600 & C-C stretch (in-ring) & Aromatics \\
\hline 2922 & C-H stretch & Alkanes \\
\hline 3418 & O-H stretch, H-bonded & Alcohols,phenols \\
\hline
\end{tabular}

Figure 8: FTIR analysis of Silver nano particles synthesized from Syringodium isoetifolium. 
Citation: Abideen S, Sankar MV (2015) In-vitro Screening of Antidiabetic and Antimicrobial Activity against Green Synthesized $\mathrm{AgNO}_{3}$ using Seaweeds. J Nanomed Nanotechnol S6-001. doi:10.4172/2157-7439.S6-001

Page 4 of 5

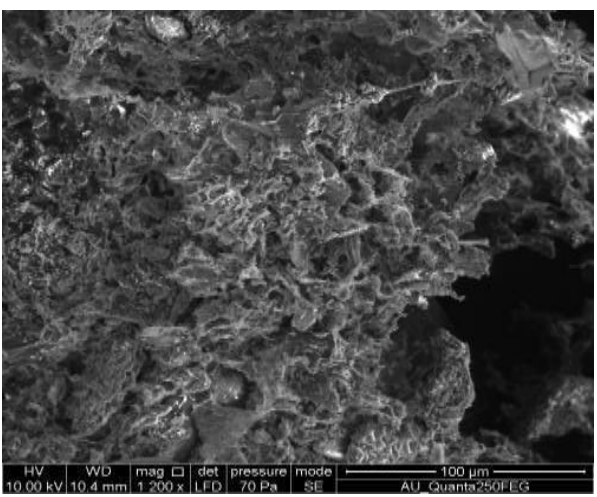

Figure 9: SEM of Gracillaria edulis.

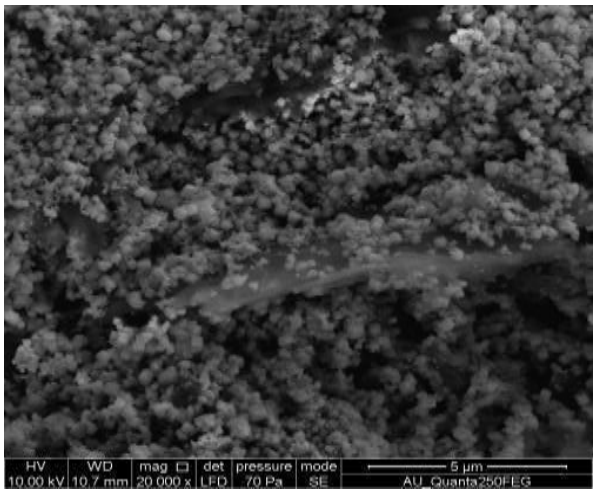

Figure 10: SEM of Syringodium isoetifolium

\begin{tabular}{|c|c|c|c|}
\hline $\begin{array}{c}\text { Name of the } \\
\text { Seaweeds }\end{array}$ & $\begin{array}{c}\text { Concentration } \\
(\boldsymbol{\mu g} / \mathbf{m l})\end{array}$ & $\begin{array}{c}\text { O.D of Absorbance at } \\
\mathbf{6 6 0} \mathbf{~ n m}\end{array}$ & $\begin{array}{c}\text { \% of } \\
\text { inhibition }\end{array}$ \\
\hline \multirow{4}{*}{ Gracillaria Edulis } & Control & 8 & - \\
\cline { 2 - 4 } & 100 & 0.7 & $68.75 \%$ \\
\cline { 2 - 4 } & 200 & 1.4 & $74.50 \%$ \\
\cline { 2 - 4 } & 300 & 0.2 & $78.21 \%$ \\
\hline \multirow{4}{*}{$\begin{array}{c}\text { Syringodium } \\
\text { Isoetifolium }\end{array}$} & 400 & 1.9 & $98.75 \%$ \\
\cline { 2 - 4 } & Control & - & - \\
\cline { 2 - 4 } & 100 & 0.1 & 42.35 \\
\cline { 2 - 4 } & 200 & 0.3 & 76.25 \\
\hline
\end{tabular}

Table 1: Inhibition of a amylase activity of synthesized silver nanoparticles from seaweeds.

\begin{tabular}{|c|c|c|c|}
\hline $\begin{array}{c}\text { Name of the } \\
\text { Seaweeds }\end{array}$ & $\begin{array}{c}\text { Concentration } \\
(\boldsymbol{\mu g} / \mathbf{m l})\end{array}$ & $\begin{array}{c}\text { O.D of Absorbance } \\
\text { at } \mathbf{6 6 0} \mathbf{~ n m}\end{array}$ & $\begin{array}{c}\mathbf{\%} \text { of } \\
\text { inhibition }\end{array}$ \\
\hline \multirow{3}{*}{ Gracillaria edulis } & Control & 8 & \\
\cline { 2 - 4 } & 100 & 1.7 & $58.75 \%$ \\
\cline { 2 - 4 } & 200 & 1.4 & $64.50 \%$ \\
\hline \multirow{3}{*}{ Syringodium } & 300 & 1.2 & $69.21 \%$ \\
\hline \multirow{3}{*}{ Isoetifolium } & 400 & 2.9 & $78.75 \%$ \\
\hline & 100 & - & - \\
\hline & 200 & 0.1 & 25.12 \\
\hline & 300 & 0.3 & 35.25 \\
\hline
\end{tabular}

Table 2: Effect of synthesized nanoparticles on glucose inhibition assay.

\begin{tabular}{|c|c|c|}
\hline \multirow{2}{*}{ Human Pathogens } & \multicolumn{2}{|c|}{ Zone of inhibition in diameter $(\mathbf{m m})$} \\
\cline { 2 - 3 } & Gracilaria edulis & Syringodium isoetifolium \\
\hline Shigella & 4 & - \\
\hline Enterobacteria & - & - \\
\hline Salmonella & - & 4 \\
\hline Vibrio & - & 6 \\
\hline Staphylococcus & 7 & 5 \\
\hline Streptococcis & - & 5 \\
\hline E-coli & 12 & 10 \\
\hline
\end{tabular}

Table 3: Antibacterial activity of synthesized silver nanoparticles of mangrove plants against in human pathogen.

\section{Conclusion}

According to the literature studies, In this regard, the size of the synthesized nanoparticles was identified between 71 and $110 \mathrm{~nm}$ with various spherical shapes, which falls closer to many of the silver nanoparticles produced by other plant materials [10-14]. It is concluded from the present findings that, the biosynthesized silver nanoparticles using aqueous extract of two sea weeds plants such as Gracillaria edulis and Syringodium isoetifolium showed significant effect on glucose utilization and also Gracilaria edulis showed potential antibacterial activity with various bacterial pathogens which could be further used as a potential antibacterial agents.

\section{References}

1. Islam N, Miyazaki K (2009) Nanotechnnology innovation system: Understanding hidden dynamics of nanoscience fusion trajectories. Technological Forecasting and Social Change 76: 128-140.

2. Chaloupka K, Malam Y, Seifalian AM (2010) Nanosilver as a new generation of nanoproduct in biomedical applications. Trends in Biotechnology 28: 580-588.

3. Cardozo KHM, Guaratini T, Barros MP, Falcão VR, Tonon AP, et al. (2007) Metabolites from Algae with Economical Impact. Comparative Biochemistry and Physiology Part C: Toxicology \& Pharmacology 146: 60-78.

4. Misawa M (1977) Production of natural substances by plant cell cultures described in japanese patents. In: Barz W, Reinhard E, Zenk MH (Eds). Plant Tissue Culture Its Bio-Technol. Springer-Verlag, Berlin, Germany.

5. Brasch DJ, Chuah CT, Melton LD (1983) Marine algal polysaccharides, Part 2. The agar-type polysaccharide from the red alga Gracilaria secundata. Carbohydr Res 115: 191-198.

6. Wild S, Roglic G, Green A, Sicree R, King H (2004) Global prevalence of diabetes: estimates for the year 2000 and projections for 2030. Diabetes Care 27: 1047-1053.

7. Xiao Z, Storms R, Tsang A (2006) A quantitative starch iodine method for measuring alpha-amylase and glucoamylase activities. Anal Biochem 351: $146-148$.

8. Shaukat A, Levitt MD, Taylor BC, Mac Donald R, Shamliyan TA, et al. (2010) Systematic review: effective management strategies for lactose intolerance. Annals of Internal Medicine 152: 797-803.

9. Gallagher AM, Flatt PR, Duffy G, Abdel-Wahab YHA (2003) The effects of traditional antidiabetic plants on in vitro glucose diffusion. Nutr Res 23: 413-424.

10. Vivekanandhan S, Misra M, Mohanty AK (2009) Biological synthesis of silver nanoparticles using Glycine max (soybean) leaf extract: an investigation on different soybean varieties. J Nanosci Nanotechnol 9: 6828-6833.

11. Gnanadesigan M, Anand M, Ravikumar S, Maruthupandy M, Vijayakumar $\mathrm{V}$, et al. (2011) Biosynthesis of silver nanoparticles using mangrove plant extract and their potential mosquito larvicidal property. Asian Pac J Trop Med 4: 799-803.

12. Chandran SP, Chaudhary M, Pasricha R, Ahmad A, Sastry M (2006) Synthesis of gold nanotriangles and silver nanoparticles using Aloe vera plant extract Biotechnology Progress 22: 577-583. 
Citation: Abideen S, Sankar MV (2015) In-vitro Screening of Antidiabetic and Antimicrobial Activity against Green Synthesized AgNO $\mathrm{Asing}_{3}$ Seaweeds. J Nanomed Nanotechnol S6-001. doi:10.4172/2157-7439.S6-001

Page 5 of 5

13. Mulvaney $\mathrm{P}$ (1996) Surface plasmon spectroscopy of nanosized metal particles. Langmuir 12: 788-800.
14. Sastry M, Patil V, Sainkar SR (1998) Electrostatically controlled diffusion of carboxylic acid derivatized silver colloidal particles in thermally evaporated fatty amine films. J Phys Chem B 102: 1404-1410. 